\&.Edu.\&Sci. , The first conference on Biology, (September-2007)

\title{
Some Ecological Aspects Of The Acanthocephalann Pomphorhynchus spindletruncatus Parasitic In Barbus xanthopterus From Lesser Zab River In North Of Iraq*
}

\author{
Shamall M. A. Abdullah** \& Furhan T. Mhaisen* \\ **Dept. Biology, Coll. Science Education, Univ. Salahaddin, \\ *Dept. Biology, Coll. Education (Ibn Al-Haitham), \\ Univ. Baghdad
}

الخلاصة

تم جمع عبنات شهرية من سمكة القطان Barbus xanthopterus خلال المدة مسن شهر تشرين الثاني 2000 ولغاية نهاية تشرين الثاني 2001 من نهر الزاب الصغير فئن في شمال

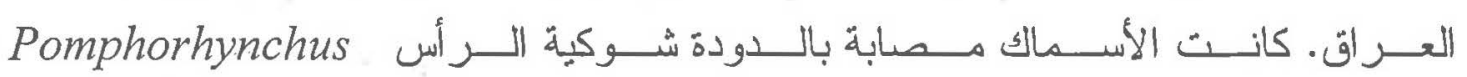
وإث spindletruncatus كانت نسبة الإصابة 28.1\%. لم تظهر فروق معنوية في إضنابة ذكور

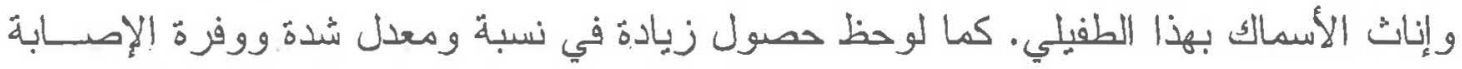

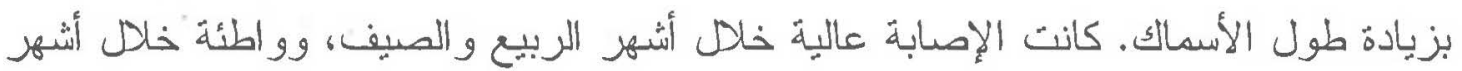

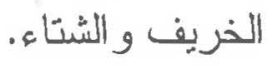

\section{ABSTRACT}

Monthly samples of the cyprinid fish Barbus xanthopterus were collected from Lesser Zab river, north of Iraq during the period from November 2000 until the end of November 2001. Fishes were found infected with the acanthocephalan Pomphorhynchus spindletruncatus. The rate of infection was $28.1 \%$. No significant differences were noticed between male and female fishes infected with this parasite. Prevalence, mean intensity and abundance of infection with $P$. spindletruncatus increased with the increase of fish length. Infection rate was high during Spring and Summer, and low during Autumn and Winter.

\section{INTRODUCTION}

Pomphorhynchus spindletruncatus Amin, Abdullah et Mhaisen, 2003 was described from north of Iraq. It is the second species of Pomphorhynchus recorded from northern Iraq (1). The other species is P. laevis (Müller, 1776) found in Dokan lake (2).

- Presented at the first conference on Biology, University of Mosul, college of Education, 4-5 September 2007 
The acanthocephalan $P$. spindletruncatus is a widely distributed intestinal parasite in two cyprinid fishes: Aspius vorax and Barbus xanthopterus in the north of Iraq. The infection is often very high (range of prevalence 33.3- 93.3\%) and it is generally considered to be pathogenic to its fish host (1).

Differences in the environmental factors, seasonal abundance of fish parasites, level of infection and other macro- and microenvironmental factors, as well as host age and sex, also play a part in determining the susceptibility of fish to diseases (3). Such informations are important for management applications to disrupt the parasite life cycle in its weakest points (4).

In Iraq, some biological and ecological information about the acanthocephalans parasitizing freshwater fishes were published. Information reported in such investigations included the seasonal changes of infection with host age, site of attachment, geographical distribution, and correlation of infestation with host sex from Shatt Al-Arab river in Basrah city (5), from Mehaijeran creek in Basrah city (6), from Greater Zab river near Erbil city (7), from Euphrates river (8) and from Dokan lake (9), As no previous account was published on the ecology of $P$. spindletruncatus in Iraq from $B$. xanthopterus which is one important commercial freshwater fish in Iraq, the present work was thought of importance to be conducted.

\section{MATERIALS AND METHODS}

Study area: The Lesser Zab river is a large river $(400 \mathrm{~km})$, located about $45 \mathrm{~km}$ south of Erbil City, in north of Iraq. It is situated between $34^{\circ}-36^{\circ}$ north latitude and $43^{\circ}-46^{\circ}$ east longitude. The sampling area in this study is located near Alton Kupri City (10).

Sampling: Monthly samples of the fish specimens were taken by gill netting, cast netting, electrofishing or hook by local commercial fishermen during the period from November 2000 until the end of November 2001.

Specimens were placed in plastic tanks with local river water and immediately transferred to the laboratory and were examined within 24 hours after their capture. However, some specimens were deeply frozen and examined within one week (11).

In the laboratory, a sample of live fish was sacrificed by pithing. Their total length, standard length and weight were measured and sex was determined. Fishes were opened from the abdominal site, the stomach and intestine were dissected out and placed in separate Petri dishes with physiological saline. All parts were thoroughly examined under a binocular microscope. Acanthocephalans found in the host were first washed in saline solution, refrigerated in cold water for 12 hours, and 
then fixed in $70 \%$ ethanol. Worms were stained with Mayer's acid carmine, dehydrated in ascending concentrations of ethanol, cleared in xylene and whole-mounted in Canada balsam (1).

During the study period, data on acanthocephalans were categorized according to sex of hosts and months of collection. Similarly, data were divided into three groups on the basis of host fish length (15-20, 21-26 and larger from $26 \mathrm{~cm}$ ).

The terms of prevalence (percentage incidence), mean intensity and abundance of infection were used according to Margolis et al. (12). For testing differences in prevalence, intensity and abundance of infection between fish sexes and length groups, two tests (t- test and complete randomized design) were conducted (13).

\section{RESULTS AND DISCUSSION}

A total of 96 B. xanthopterus from Lesser Zab river were collected during the present study. Intestines of these fishes were infected with P. spindletruncatus (Fig. 1). The overall prevalence was $28.1 \%$, the mean intensity was 14.4 and the abundance was 4.3 (Table 1 ).

\section{Variations in Infection with Host Sex}

Table (1) indicates that males and females of B. xanthopterus from Lesser Zab river showed no significant differences in their infection rate with $P$. spindletruncatus $(t=0.31$ at $\mathrm{P}<0.05)$. For this reason, data for both sexes were pooled for further analysis. The present result agrees with that of Kennedy (4) who noted that many workers showed absence of any difference in the infection of both sexes with most parasites. 


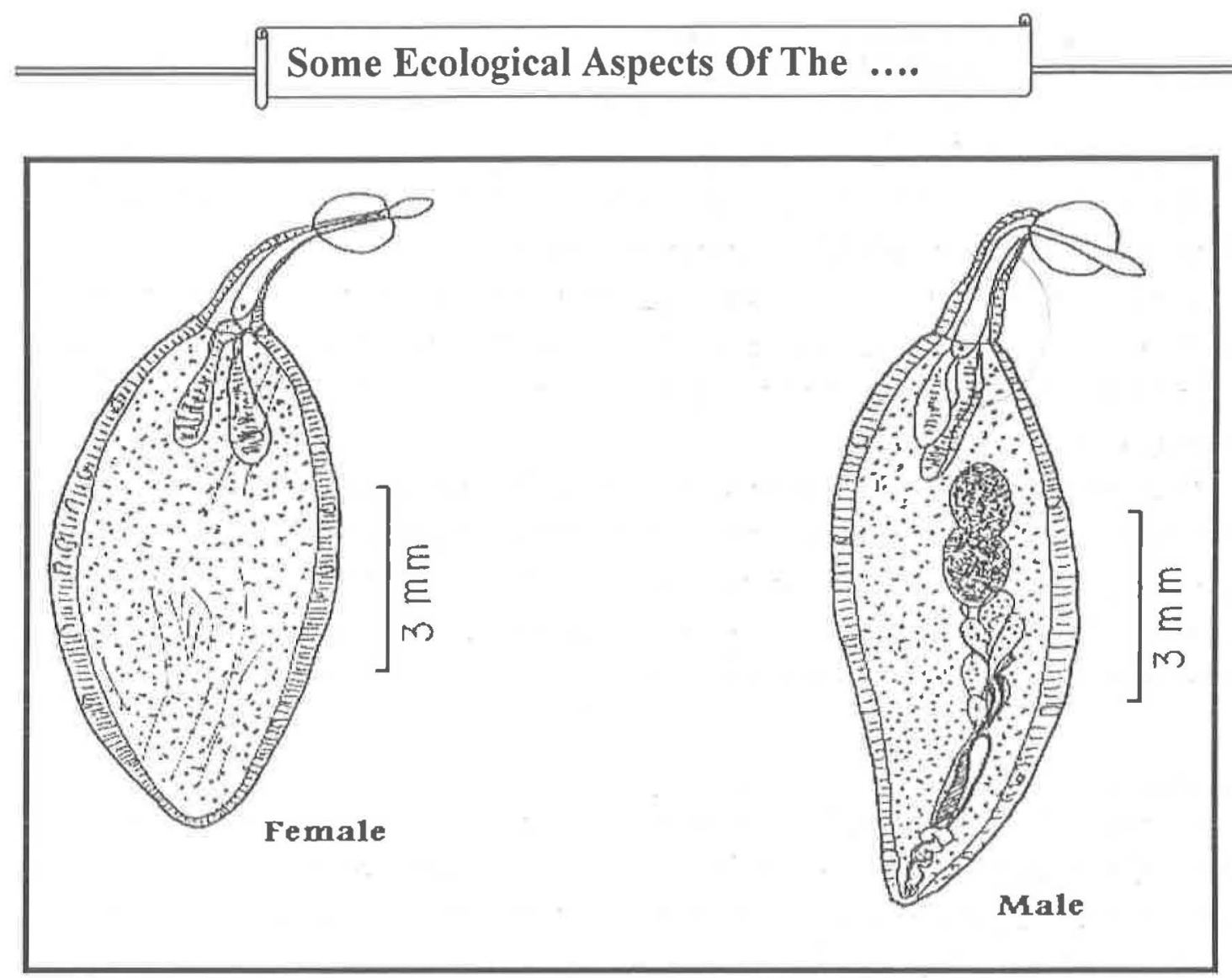

Fig. (1): Camera lucida drawings of Pomphorhynchus spindletruncatus.

This result also confirms observations of Ali (7) on Neoechinorhynchus rutili of Barbus esocinus in Greater Zab river. The similarity of the food and feeding habits of males and females of fishes and their occupancy of the same habitat (14) may explain the absence of any difference in the parasitic fauna acquired with food of both sexes. Living in the same habitat and the absence of morphological differences between both sexes of fishes may also provide evidences on the similarity of the infection with parasites as well. However, some authors gave examples on the presence of such differences between males and females $(9,14)$ due to differences in food behavior and morphological differences between both sexes.

Table 1: Changes of the infection of different sex of $B$. xanthopterus with $P$. spindletruncatus from Lesser Zab river.

\begin{tabular}{|c|c|c|c|c|c|c|}
\hline \multirow{2}{*}{$\begin{array}{l}\text { Fish } \\
\text { sex }\end{array}$} & \multicolumn{2}{|c|}{ No. Fish } & \multirow{2}{*}{$\begin{array}{c}\text { Prevalence } \\
(\%)\end{array}$} & \multirow{2}{*}{$\begin{array}{c}\text { No. } \\
\text { parasites }\end{array}$} & \multirow{2}{*}{$\begin{array}{c}\text { Mean } \\
\text { intensity }\end{array}$} & \multirow{2}{*}{ Abundance } \\
\hline & examined & infected & & & & \\
\hline Male & 49 & 14 & 28.6 & 210 & 15.0 & 4.3 \\
\hline Female & 47 & 13 & 27.7 & 178 & 13.7 & 3.8 \\
\hline Both & 96 & 27 & 28.1 & 388 & 14.4 & 4.0 \\
\hline
\end{tabular}




\section{Variations in Infection with Host Length}

The present resultsshowed an increase in the infection rate of $B$. xanthopteris with $P$. spindletruncatus with the increase of fish length. The intensity and abundance of infection was high $(6.2 \pm 2.7)$ in the largest fish length group (larger from $26 \mathrm{~cm}$ ). The statistical analysis showed no significant differences $(p=0.05)$ between the groups of fish length (Table 2).

The increase in the infection rate with $P$. spindletruncatus can be attributed to the accumulation of the infective stages consumed with the intermediate host, or may result from a relatively stable host feeding behavior in all ages. This agrees with the results found by some researchers in Iraq for $N$. rutili in B. esocinus (9) for $N$. iraqensis in Liza abu (16), and for $N$. rutili in $B$. barbus of the Jihlava river, Czech Republic (17)

Table 2: Changes of the infection rate of different length group of $B$. xanthopterus with $P$. spindletruncatus from Lesser Zab river.

\begin{tabular}{|l|c|c|c|c|c|c|}
\hline $\begin{array}{c}\text { Fish } \\
\text { length } \\
\text { group } \\
(\mathrm{cm})\end{array}$ & $\begin{array}{c}\text { No. fish } \\
\text { examined }\end{array}$ & $\begin{array}{c}\text { No. fish } \\
\text { infected }\end{array}$ & $\begin{array}{c}\text { Prevalence } \\
(\%)\end{array}$ & $\begin{array}{c}\text { No. } \\
\text { parasites }\end{array}$ & $\begin{array}{c}\text { Mean } \\
\text { intensity }\end{array}$ & $\begin{array}{c}\text { Abundance } \\
\pm \mathrm{SD}\end{array}$ \\
\hline $15-20$ & 17 & 3 & 17.6 & 16 & 5.3 & $0.9 \pm 0.5$ \\
\hline $21-26$ & 41 & 12 & 29.3 & 138 & 11.5 & $3.4 \pm 1.9$ \\
\hline $\begin{array}{l}\text { Larger } \\
\text { from 26 }\end{array}$ & 38 & 12 & 31.6 & 234 & 19.5 & $6.2 \pm 2.7^{*}$ \\
\hline
\end{tabular}

* Highest infection

\section{Seasonal Variations in Infection}

It is apparent that $P$. spindletruncatus occurred in $B$. xanthopterus throughout the year except November and February, with a prevalence attaining of $10-87.5 \%$. The infection of $B$. xanthopterus with this parasite in Lesser Zab river showed significant differences $(p=0.05)$. The abundance of infection (Table 3) was highest during July (20.9 \pm 1.7$)$, and lowest during September $(0.7 \pm 1.2)$.

The increase in infection rate with $P$. spindletruncatus during Summer may be the result of abundance of a large number of the intermediate hosts in the water (18) and the increase in the feeding activity of the fishes. The low infection rate during Winter can be attributed to both lower feeding activity of the fishes and the rarity of larval stages that infect fishes (19). Similar trends in the fluctuations in prevalence were noted in case of $N$. agilis from $L$. abu in Mehaijeran creek, in Basrah city (6) and N. rutili from B. esocinus in Dokan lake (9). 
The findings of this study also confirm the suggestion made by Granath and Esch (20) that seasonal changes in abundance of fish parasites are influenced by a variety of factors including temperature and food consumption.

Table 3: Monthly fluctuations of the infection of $B$. xanthopterus with $P$. spindletruncatus from Lesser Zab river.

\begin{tabular}{|l|c|c|c|c|c|c|}
\hline Month & $\begin{array}{c}\text { No. fish } \\
\text { examined }\end{array}$ & $\begin{array}{c}\text { No. fish } \\
\text { infected }\end{array}$ & $\begin{array}{c}\text { Prevalence } \\
(\%)\end{array}$ & $\begin{array}{c}\text { No. } \\
\text { parasites }\end{array}$ & $\begin{array}{c}\text { Mean } \\
\text { intensity }\end{array}$ & $\begin{array}{c}\text { Abundance } \\
\pm \text { SD }\end{array}$ \\
\hline $\begin{array}{l}\text { Nov. } \\
2000\end{array}$ & 6 & 0 & 0 & 0 & 0 & 0 \\
\hline Dec. & 10 & 2 & 20 & 18 & 9 & $1.8 \pm 2.2$ \\
\hline $\begin{array}{l}\text { Jan. } \\
2001\end{array}$ & 8 & 2 & 25 & 19 & 9.5 & $2.4 \pm 2.5$ \\
\hline Feb. & 6 & 0 & 0 & 0 & 0 & 0 \\
\hline Mar. & 9 & 2 & 22.2 & 14 & 7 & $1.6 \pm 1.6$ \\
\hline Apr. & 9 & 2 & 22.2 & 25 & 12.5 & $2.8 \pm 3.3$ \\
\hline May & 8 & 2 & 25 & 34 & 17 & $4.3 \pm 4.9$ \\
\hline June & 8 & 3 & 37.5 & 49 & 16.3 & $6.1 \pm 3.7$ \\
\hline July & 8 & 7 & 87.5 & 167 & 23.9 & $20.9 \pm 1.7$ \\
\hline Aug. & 8 & 5 & 62.5 & 47 & 9.4 & $5.9 \pm 2.0$ \\
\hline Sept. & 10 & 1 & 10 & 7 & 7 & $0.7 \pm 1.2$ \\
\hline Oct. & 6 & 1 & 16.7 & 8 & 8 & $1.3 \pm 1.3$ \\
\hline
\end{tabular}

* Highest infection

$\mathrm{LSD}=1.20$. 


\section{REFERENCES}

1- Amin O. M.; Abdullah S. M. A. and Mhaisen F. T., Syst. Parasitol., 54: 229-235 (2003).

2- Abdullah S. M. A., Ph. D thesis. College of Science. University of Salahaddin (1990). (In Arabic).

3- Meyer F. P., Amer. Fish. Soc., Spec. Publ., 5: 21-29 (1970).

4- Kennedy C. R., "Ecological animal parasitology". Blackwell Sci. Publ., Oxford (1975).

5- Al-Hadithi I. A.; Habash A. H. and Daoud Y. T., J. Gulf Arab. Penins. Stud., Kuwait, 24: 127-139 (1980).

6- Khamees N. R. and Mhaisen F. T., J. Biol. Sci. Res., 19(2): 409-419 (1988).

7- Ali B. A-R., M. Sc. Thesis. College of Science. University of Salahaddin (1989). (In Arabic).

8- Al-Alusi M. A-S. Ph. D. Thesis. College of Science. University of AlMustansirya (1998). (In Arabic).

9- Abdullah S. M. A. and Ali L. A., Zanco, 11(1): 17-25 (1999).

10- Al-Saudi A. F., Little Zab regin in Iraq. Asad Press. Baghdad (1976).

11- Brown A.F.; Chubb J.C. and Veltkamp C.J., J. Fish Biol., 28: 327334 (1986).

12- Margolis L.; Esch G. W.; Holmes J. C.; Kuris A. M. and Schad G. A., J. Parasitol., 68(1): 131-133 (1982).

13- Campbell R. C., "Statistics for biologists". Cambridge Univ. Press (1976).

14- Dogiel V. A., "Ecology of the parasites of freshwater fishes". In: Dogiel V. A.; Petrushevski G. K. and YU. I. Polyanski YU. I. (Eds.). Parasitology of fishes (Engl. Transl.). Oliver \& Boyd Ltd., Edinburgh \& London (1961).

15- Measures L. N., Can. J. Zool., 66: 2212-2222 (1988).

16- Al-Sady R. S., M. Sc. Thesis. College of Education (Ibn Al-Haitham) University Baghdad (2000). (In Arabic).

17- Moravec F. and Scholz T., Parasite, 1(3): 271-278 (1994).

18- Ginetsinskaya T. A., The life cycles of fish helminths and the biology of their larval stages. In: Dogiel V. A.; Petrushevski G. K. and YU. I. Polyanski YU. I. (Eds.). Parasitology of fishes (Engl. Transl.). Oliver \& Boyd Ltd., Edinburgh \& London (1961).

19- Moravec F.; Konečný R.; Baska F.; Rydlo M.; Scholz T.; Molnár K. and Schiemer F., Stud. CSAV, Acad. Praha, 3/97: 96pp. (1997).

20- Granath W. O. and Esch G. W., Proc. Helminthol. Soc. Wash., 110: 314-323 (1983). 